\title{
Kenneth S. Warren, M.D. June 11, 1929-September 11, 1996
}

\author{
by Richard Selzer, M.D.
}

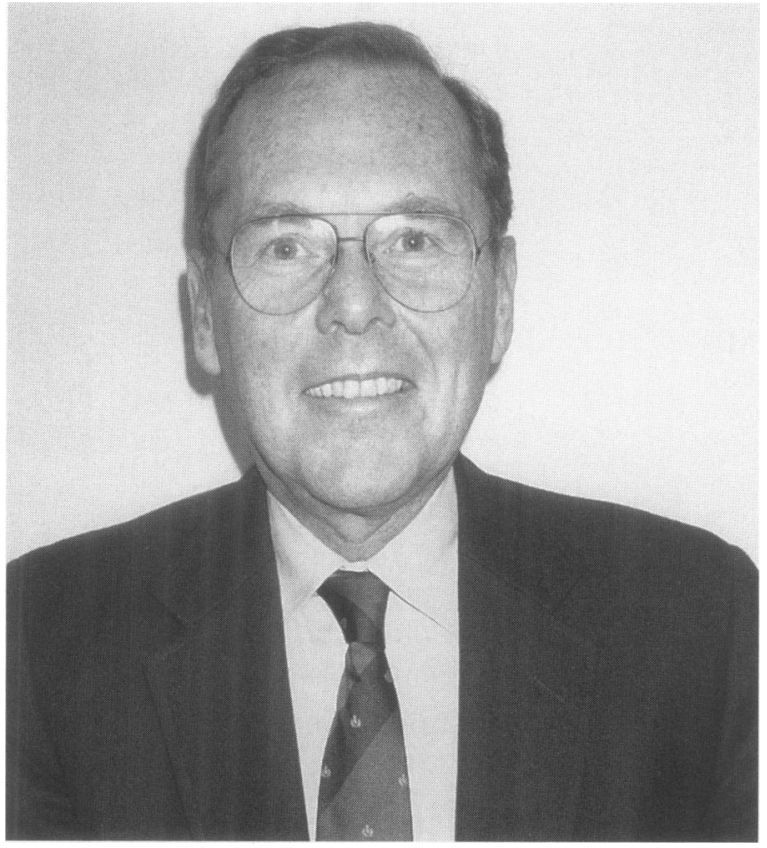

Ken Warren has died. He was a boy of sixtyseven. I say "boy" because he retained throughout his life all the enthusiasm and energy that he must have had at seventeen. If his body aged and was at last to betray him, his mind remained lively, sparkling, and faithful to the end. First, the facts:

Born in Brooklyn in 1929, Ken Warren graduated cum laude from Harvard in 1951. From there he went on to Harvard Medical School, graduating in 1955, again cum laude. Early on, he knew that the conventional practice of medicine was not for him, and that Tropical Medicine was. Accordingly, he attended the London School of Hygiene and Tropical Medicine from 1958 to 1959. He spent eight years at the National Institute of Health in the Laboratory of Tropical Diseases. Next came fourteen years at Case Western Reserve School of Medicine where he became Professor of Medicine and of Library Science. From 1977 to 1987 he was Director of Health Sciences at the Rockefeller Foundation. His last years were spent first as Director of Science at Maxwell Communications Corporation and finally at the Picower Institute for Medical Research where he was Vice President of Academic Affairs.

Among his many achievements was the creation of highly efficient, low-cost medical library and health information systems for the developing world. If ever a scientist could be called a citizen of the world, it was Ken Warren. He crossed and criss-crossed the continents as though they were neighboring counties. There is scarcely a part of the world where he has not traveled for the cause of world health.

Throughout his investigative career, Dr. Warren published hundreds of scientific papers, many on the subject of schistosomiasis, malaria, and hookworm. Not the least of his legacies is the journal Molecular Medicine, which he founded.

A lifetime parallel interest was literature, in which he majored at Harvard, writing his honors thesis on the poet T. S. Eliot. It was through writing that I first came to know Dr. Warren. I was a literary guest of the Rockefeller Foundation at their Bellagio Study Center in Italy. Ken was there on one of his thirty-five visits to that facility where he gathered together the leading scientists and scholars in the Health Sciences and conducted seminars. It was his deep interest in books that brought us together. From then on, he followed my career in writing with an excitement that was infectious. Lewis Thomas was another benefactor of Ken Warren's high spirits and creative energy. Thomas' final collection of essays was edited and published at Scribner's under the aegis of Dr. Warren.

All who knew Dr. Warren recognized that they were in the presence of one of those rare contagious personalities for whom anything was 
possible. He would not take no for an answer. This caused some to hide out until we were quite sure he was fully engaged in another project. The institutions and colleagues he served were lucky indeed to have him within their reach. He was a straightshooter, utterly incapable of guile and blessed with a delightful sense of humor.

Ken's battle with malignant melanoma be- gan more than twenty years before his death. Virulent and dreadful as is this tumor, it was polite enough to spare Ken Warren for that length of time so that he could live in comfort and continue to bring about the grand innovations which were his trademark. We all join in extending our sympathy to his wife Sylvia and his two children, Christopher and Erica. 